\title{
ミトコンドリアの遺伝子発現と酵素活性に対する運動の影響
}

\author{
下 村 吉 治
}

\section{Effects of exercise on mitochondrial gene expression and enzyme activities}

Yoshiharu Shimomura

ミトコンドリアは練胞内呼吸を通して効率よく ATP を合成する細胞内小器官である（図 1)。運 動は，生体の工ネルギ一消費を高酸素必要量を 增大するので，筋細胞のミトコンドりアにおける 細胞内呼吸とエネルギー生産系に大きな影響を及 ぼす。細胞内のエネルギ一代謝においてその基質 となるのがグルコース，脂肪酸，およびアミノ酸 であるが，これらの基質が分解される代謝系の主 要部分はミトコンドリア内に存在し，ATP生産 系と共役している。

まだ。ミトコンドリアは，核とは独立した遺伝 子(ミトコンドリアDNA: mtDNA) そタンパ ク質合成系学持つ唯一の細胞内小器官であり，生 体に与えられる刺激に上りその mtDNA からの タンパク質の発現が変化するばかりでなく，mtDNAの複製にも影響が及ぶことが知られている (Clayton, 1991)。これぁでの報告 (Rabinowwitz and Zak, 1975; Narasimhan and Attardi, 1987）では，細胞の工ネルギー需要が增加する とミトコンドリアのタンパク質発現やmtDNA の複製が促進されるごとが盟らか心されているの で，運動はそれらに影響を及ぼすことが十分に考 えられる。

これまでに，我々は，運動がミトコンドリアの 遗云子発現および各代謝系の酵素活性に及ほす影 響について検討を加え饬る程度の結果が得られた ので、ここではそれらを中心にミトコンドリアに 対する運動の影響について述べる。

\section{1. ミトコンドリアDNA (mtDNA) および 呼吸鎖酵素に対する運動の影響}

細胞内の遺伝子は，その99\%以上が核に存在 するが，核以外の細胞内小器官ではミトコンドリ アが固有の遺伝子 (mtDNA) をもつ. 人の $\mathrm{mtD}$ NAの大きさは，核DNA と比べてはるかに小さ く16,569塩基対から成る. ミトコンドリアには多 くの酵素が存在するが，その95\%以上が核 DNA によってコードされている. mtDNA がコードし ているタンパク質は13のみであり，全て呼吸鎖 の酵素複合体とATP 合成酵素のサブュニット(約 60)の一部である。すなわち，ミトコンドリア のほとんどの酵素は。細胞質で合成された後ミト コンドリア内へ輸送されており，また，呼吸鎖の 酵素複合体とATP 合成酵素は核 DNA と $\mathrm{mtD}$ NAの協調発現の結果生成されるのである.

mtDNAの発現と複製に対する筋収縮の影響 は，Williamsら（1986）により詳細に検討され 1986年に報告された。彼等は，ウサギの片方の 下肢に電極を埋め込み，電気刺激により筋収縮を 誘発し５日間むしくは21日間の連続的な筋収縮 の影響を，もう一方の電気刺激しない下肢の筋肉 と比較することにより検討した。 その結果，5 日 間では mtDNA 量およびその発現には影響は認 められなかったが，21日間の刺激によりそれら は6〜7倍にも增加することを観察した。しかし ながら，この電気刺激による笳肉の收縮は，筋夕
名古屋工業大学共通講坐健康運動科学

T466-8555 愛知買名古屋市昭和区御器所町
Department of Bioscience, Nagoya Institute of Technology, Gokisocho, Showa-ku, Nagoya, Aichi 466-8555 


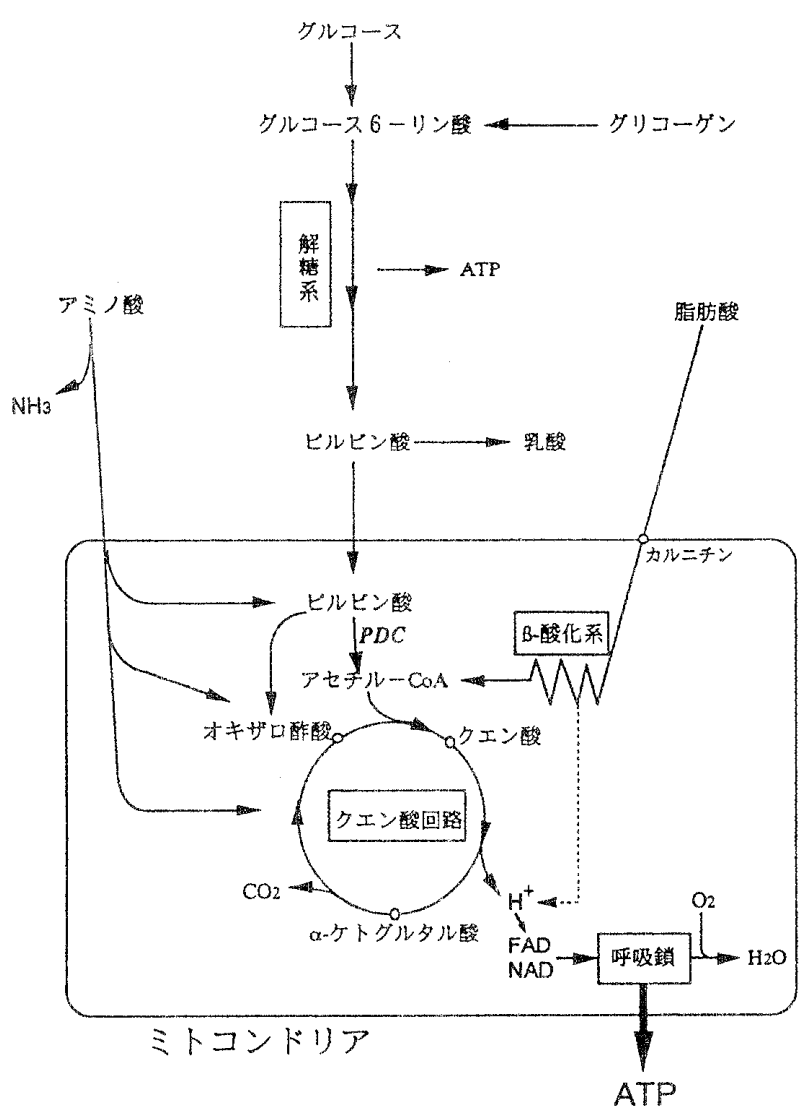

图 1 細胞内のエネルギ一代謝系 $P D C:$ :゚ルビン酸脱氷素醅素複合体

ソパクの減少を引き起こすなどの自然の運動とは 異なる生理的現象も伴っていた (Williams et al, 1987).

そこで我々は，自然の運動が骨格筋の mtDNA 量とその発現および酵素活性に及ほす影響をラッ トを用いて検討した（Murakami et al., 1994）。 ラットにトレッドミルを用いて1 日90分間走ら 女る運動負街 $\left(25 \mathrm{~m} /\right.$ 分。登勾配 $\left.6^{\circ}\right)$ 孛 3,6 女 しくは12週間 (5 日/週) 行った。炎の結果，筋 ミトコンドリアのクエン酸合成酵素，呼吸鎖の酵 素複合体の活性は 3 週間のトレーニングで1.31.6倍に増加し，12週間の運動負荷後もそのレベ ルを維持した（図2）。またミトコンドリア RNA（シトクロームbmRNA）量も同様な傾向 を示したが，mtDNA 量は12週間の長期トレー二 ソグによっての文1.4倍に增加した（因2）。すな わち、トレーニングに対ずるミトコンドリアの谪 応は，すず酵素発現を増加することにより起こ
り，トレーニングが長期にわたるとミトコンドリ アの数を増加することにより起こると考えられ る. しかし，走運動の場合は，電気刺激による筋 収縮のような数倍にもおよぶ mtDNA 及びその 発現の増加は認められず，いずれも 2 倍以下の 増加であった。

どのようなメカニズムによって運動の刺激がミ トコンドリアの遺云子発現の促進および酵素活性 の上昇をむたらすのかは興味深い問題でありここ れらを明らかにしていくことが運動を科学する研 究の最も重要な課題の一つであろう.

これまでに，mtDNAおよび核DNAの協調発 現を調節する因子がいくつか発見されており，そ の重要な一つが nuclear respiratory factor-1 (NRF-1) である (Clayton, 1991). あた, NRF1 と同様にその発現を調節する因子として, 癌遺 厷子である c-fos や c-jun などの immediately early gene（最初期遺伝子）の存在か示唆されてい る(Cano and Mahadevan, 1995). そこで我々 は，これらの調節因子の mRNAの発現に対する 1 回の運動の影響を検討した（Murakami et al., 1998). トレ一ニングしていないラットに $25 \mathrm{~m} /$ 分の速度の走運動を90分間負荷した後， $0.5 ， 3 ， 6$, 24 時間の時点でラットよりとラメ筋を摘出し, cytochrome oxidase のサブユ ニットIII (mtDNAにコードされる)とサブュニット Vc（核 DNA ヒコードされる）の mRNA 量を Northern blotting 法で, NRF-1の mRNA 量, 抢よびcfos とc-jun の mRNA 量を reverse transcriptionpolymerase chain reaction ( $\mathrm{RT}-\mathrm{PCR}$ ) 法で測定 した。その結果, 1 回の運動負荷では cytochrome oxidase のいずれのサブュニットの mRNA 量の增加も認められなかったが，NRF-1の mRNA は運動後 6 時間の時点でのみ有意に增加 した（図3）。むた，c-fosの mRNAは運動後30 分にピークがあり，その後漸減したが 6 時間の 時点まで有意な増加が認められた（図3）.c-jun の $\mathrm{mRNA}$ 量注, 運動後 3 時間の時点でのみ有意 な增加が認められた（図3）。

さらに我々は，5日間（90分/日の走運動負荷） のトレーニングを行なった後, 6 日目に同様に走 


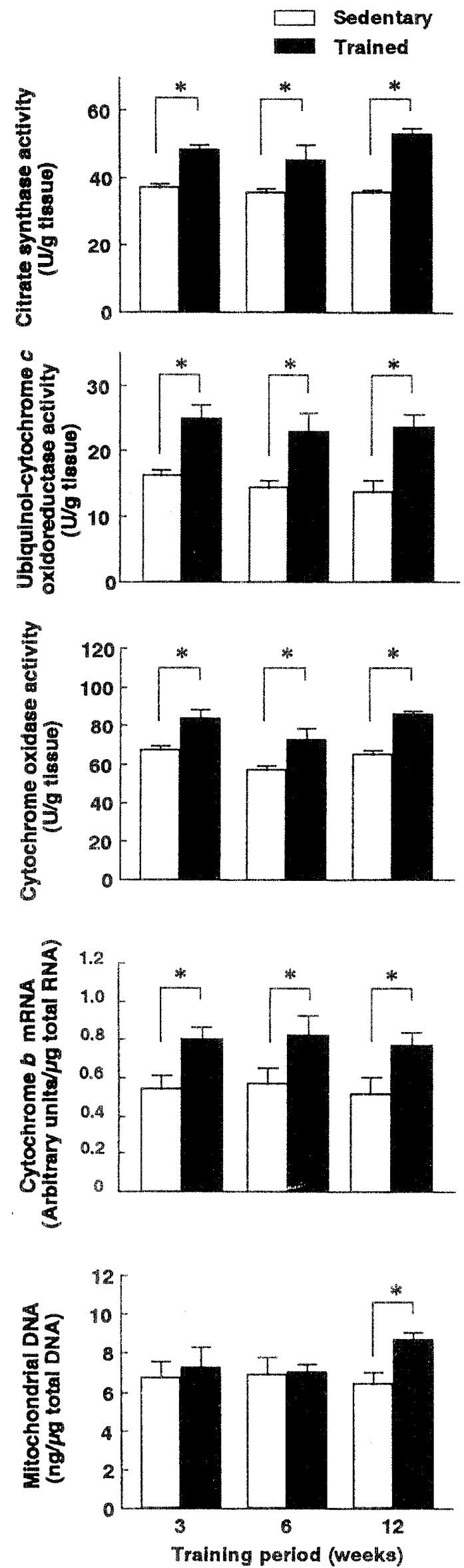

運動を負荷しそその後同し時間経過で筋肉を採取 し同様な分析を行なった（Murakami et al., 1998)。その結果，5 日間のトレーニングにより， cytochrome oxidase の両サブュニットの mRNA 量の有意な增加が認められた（図4）。 また， NRF-1 の mRNA 量む運動後 6 時間の時点で一 過性の増加が認められた（図 4)。たたし，その 增加の程度はトレーニングしないラットよりも幾 分小さい傾向にあった。一方，c-fos とc-junの mRNA 量は運動後有意な増加は認められなかっ た（図 4)。これらの結果より，cytochrome oxidase ザブュニットの mRNA 量の増加には, immediately early gene や NRF-1 の発現増加が関 与していることが示唆されると同時に，一定強度 でレーニングした後では，immediately early gene の mRNA 発現を促進するにはさらに高い 強度の運動負荷が必要であろうと推測される。す なわち、トレーニングの効果を十分に発揮するた 奶には，運動強度を徐々に上げていく必要がある ことの説明が分子レベルで可能であると考えられ 万.

\section{2. グルコ一ス代謝と脂肪酸代謝の調節酳素に 対する運動の影響}

グルコースは，解糖系により分解されピルビン 酸を生成し，ピルビン酸はミトコンドリア内に存 在するピルビン酸脱水素醅素 (pyruvate dehydrogenase: PDH) 複合体によりアセチルー CoAに変換され，最終的にクエン酸回路で完全 酸化される（図 1)。よって，PDH 複合体はグル コ一ス代謝の重要な調節酵素の一つである（Be-

図 2 長期間の持久運動がヒラメ筋のミトコンドリ ア内醳素の活性, mRNAの発現, およびミ トコンドリアDNA 複製に及ほす影響 (Murakami et al., 1994より引用) 各値は平均值士標準誤差で表した $\left({ }^{*} \mathrm{P}<\right.$ 0.05)。トレーニング群のラットには, トレ ット゚ミルを用いて 3,6 , およよ゙12週間のトレ 一ニングを負荷したトレーニング方法： $25 \mathrm{~m} /$ 分， 90 分 $/$ 日， 5 日/遇 

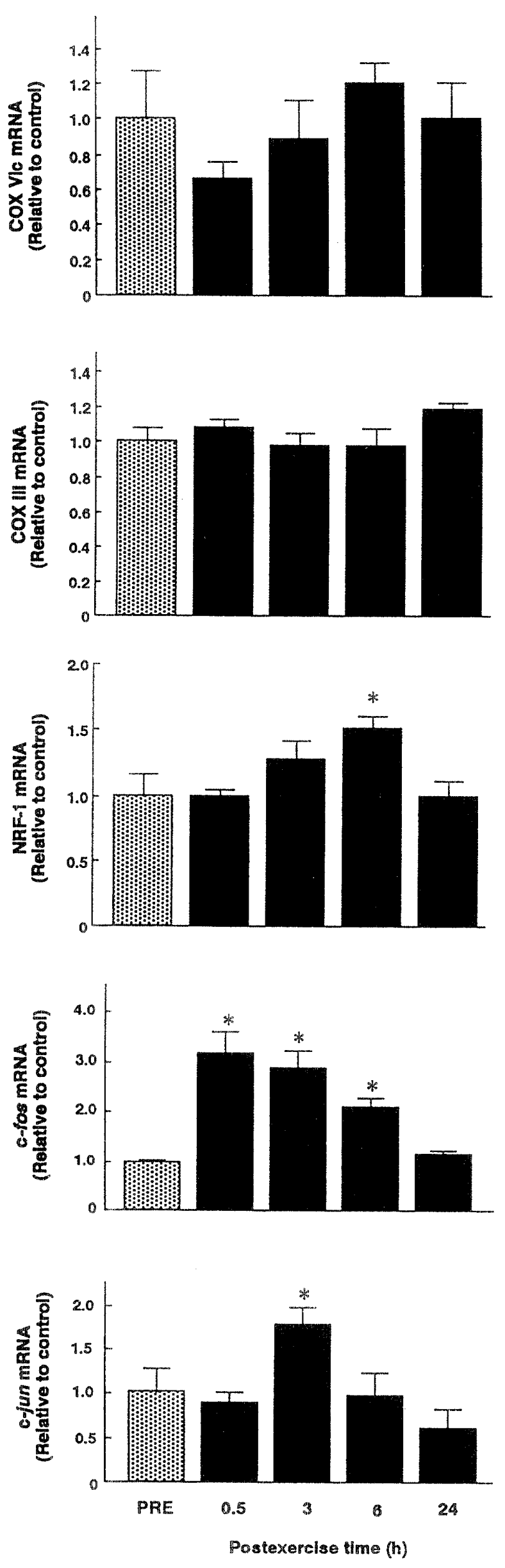

hal et al., 1993). PDH 複合体活性は, 酵素タン パク質のリン酸化により調節されることが明らか にされており，活性型酵素は脱リン酸化型で，リ ン酸化により失活する（Behal et al., 1993）（図 5).よって, 組織内の活性型酵素の割合い（activity state）は, in vivoの代謝状態を反映する と考えられている。一方, 脂肪酸はミトコンドリ ア内の $\beta$-酸化系により分解され，最終的にアセ チル-CoA を生成し，クエン酸回路で分解され る.従って，グルコースと脂肪酸は分解されると ミトコンドリア内で同一の代謝中間体（アセチル 一CoA）を生成するため，両者の代謝は拮抗する 関係にある (Behal et al., 1993)。

ラットに運動トレーニングを 8 週間負荷した 後, 笳肉の $\mathrm{PDH}$ 複合体と $\beta$-酸化系の 3 -ヒトロロ キシアシル-CoA 脱水素酵素の活性を測定する

と，前者の活性は約 $55 \%$ に減少し，後者の活性 は144\%に増加していた（図6)。すなわち，運動 トレーニングにより，グルコースは分解されにく く，脂肪酸は酸化分解され易い状況が骨格筋にも たらされると考えられる。一般的に，運動トレー ニングは脂肪の利用性を高め，グルコ一スを節約 ずる状況を筋肉にもたらすことが知られている が。これらの䤉素活性の変化によりその代謝調節 のメカニズムが説明できると考えられる。

\section{3. 分岐鎖アミ/酸代謝系酵素と運動}

運動は筋肉のみならずその他の組織のタンパク 質の分解をえ進する.タンパク質には分岐鎖アミ

一回の持久運動がヒラメ筋のチトクローム酸 化酵装, nuclear respiratory factor-1 (NRF1)，c-fos，志上びc-jun の遺层子発現に及ほ す影籍（Murakami et al., 1998より引用）。 mRNAの定量は，ノーザンブロット法（チ トクローム酸化醉素サブュニット Uc（COX Vic) とサプュニットII (COX III)，ぬたは 定量的近転写ポリメラーゼ連鎖反応（RT$\mathrm{PCR})$ 法 (NRF-1,c-fos，およびc-jun）で 行い，運動前コントロール (PRE) に対す る値として表した，各值は平均值士硒準誤差 で表した $\left({ }^{*} \mathrm{p}<0.05\right)$. 

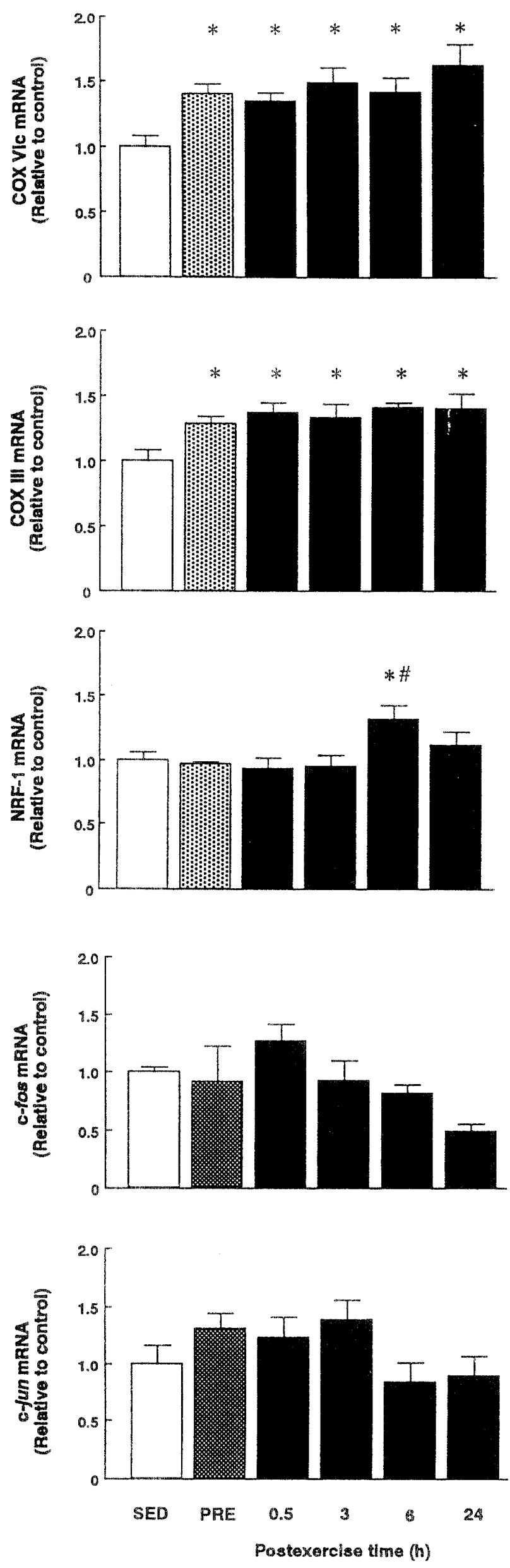

酸（ロイシン，イソロイシン，バリン）の含量 が高いので，タンパク質の分解により細胞内の分 岐鎖了ミノ酸濃度が上昇する．分岐鎖アミノ酸の 分解系は全てミトコンドリア内に存在し，その律 速酵素は，分岐鎖 $\alpha$ 一ケト酸脱水素酵素（branched-chain $\alpha$-ketoacid dehydrogenase: $\mathrm{BCKDH}$ ) 複合体である (Harper et al., 1984; Shimomura, 1996)。BCKDH 複合体の活性も，PDH 複合体 上同様に酵素タンパク質のリン酸化により調節さ れる（Shimomura，1996）（図7）。すなわち，活 珄型酵素は脱リン酸化型で, リン酸化により失活 するるので，組織内の活性型酵素の割合い（activity state）は，in vivoの状況を反映すると考えら れる。筋肉の $\mathrm{BCKDH}$ 複合体は，何も刺激が加 えられない状態では極めて低い活性状態である が，基質の濃度が上昇すると活性化される機構が 存在する (Shimomura, 1996; Shimomura et al.,

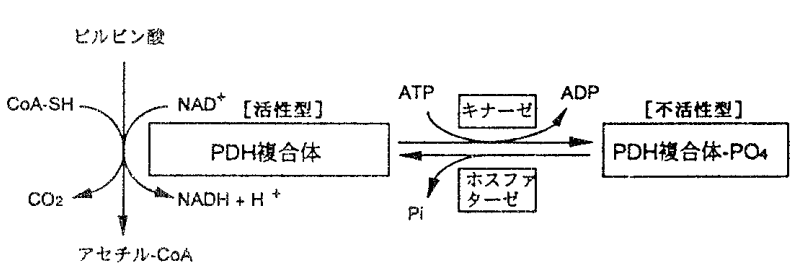

图 5 リン酸化抢よび脱りン酸化によるピルビン酸 脱水素酵素 (PDH) 複合体の活性調節

図4 短期間の持久運動がヒラメ筋のチトクローム 酸化醅素, nuclear respiratory factor-1 (NRF-1)，c-fos，およびc-jun の遗伝子発現 に及ほす影響（Murakami et al., 1998より引 用)。

mRNA の定量は，ノーザンプロット法（チ トワローム酸化醅素サブュニットVC（COX Vc)とサプュニットIII（COX III），または 定量的逆転写ポリメラーゼ璉鎖反応（RTPCR) 法 (NRF-1,c-fos, およびc-jun) で 行い，安静コントロール(SED) に対する 值として表した。PREは最後の運動を行う 前のコントロール. 各值は平均值士標準誤差 で表した（*P<0.05; SED との比皎，\#P< 0.05 ; PRE との比較). 

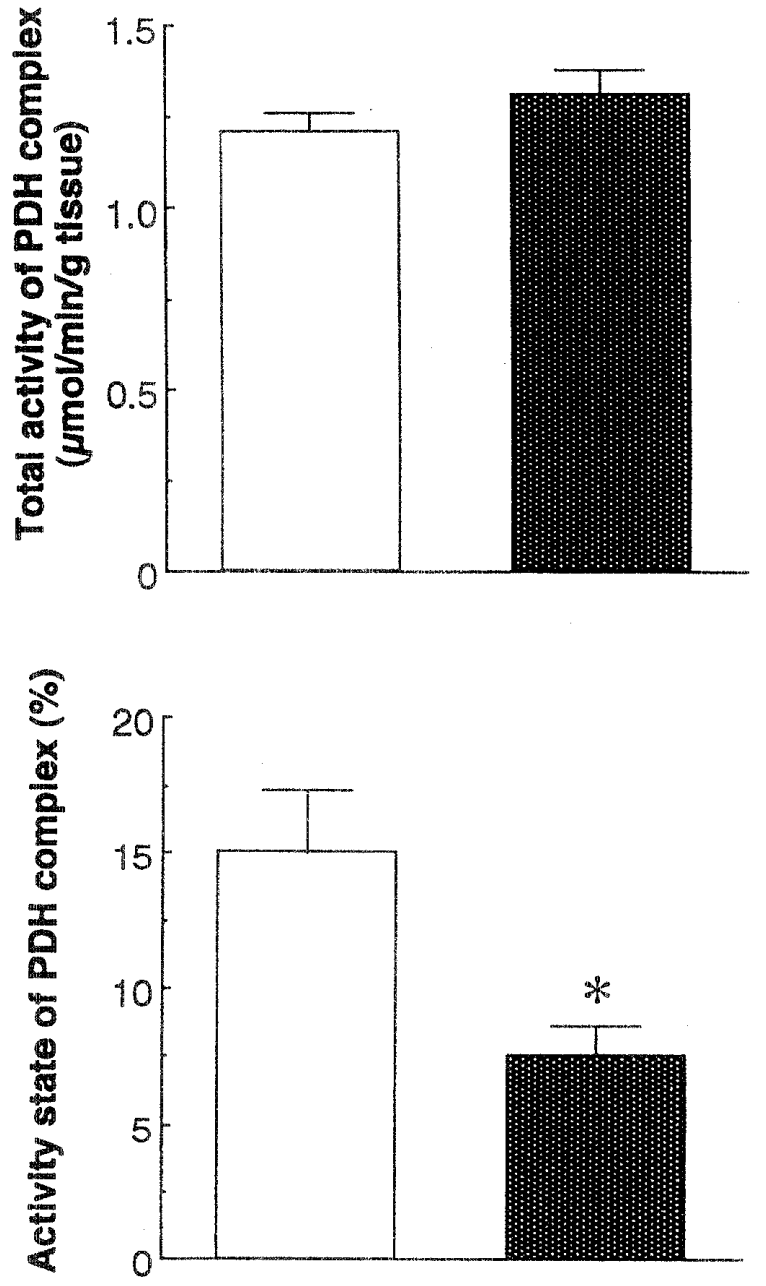

1993; Fujii et al., 1994）（図 8）。従って，運動は 筋肉の $\mathrm{BCKDH}$ 複合体活性を上昇し，分岐鎖了 ミノ酸の分解を促進する。この運動刺激が繰り返 して加えられトレーニングされた筋肉では，非卜 レーニングの筋肉に比べて BCKDH 複合体の酵 素量が增加して招り，さらに安静状態の活性も高 い(Fuji et al, 1995)（図 9). 徒って,トレー二 ソグは運動時の多ならず安静時の筋肉にお汁る分 岐鎖アミ/酸の代謝を促進する状況をむだすと 考えら机る。五の所見は，アスり一トか一般の人 上り必多くの领事タンパク質を必要とする基礎的 なメカニス゚ムの一つで斿ると考えられる。

以上の上うに，運動は筋肉ミトコンドリアのエ ネルギー生産系に影響を及ぼすが，ての運動に対 するる反広のメ力二ズムは遺伝子の発現や䤃素活性 の調節に上り説明される。しかしながら，現在明

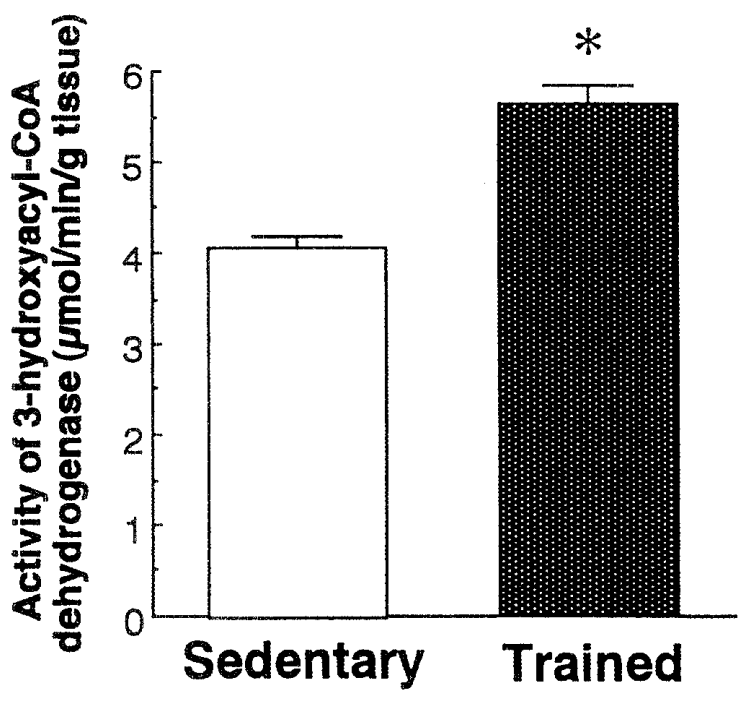

図 6 ラット腓腹筋 PDH 複合体の総活性と活性型 醇素の割合、および3ーヒドロキシアシルー $\mathrm{CoA}$ 脱水素醅活性に対する8週間のトレ -ニング效果

各值は平均值と標準䛊差で示した（ ${ }^{*} \mathrm{p}<$ 0.05)。トレーニング群のラットは回転車輪 付ケージで飼育し，自由走行運動を 8 週間 行わせた。

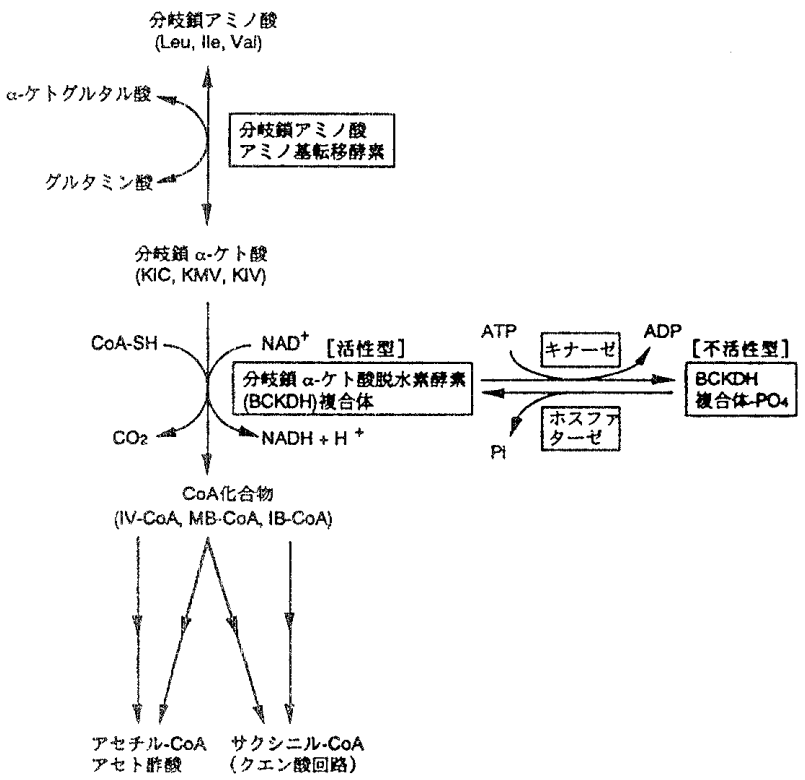

図7分岐鎖アミノ酸の代謝とその調節

$\mathrm{BCKDH}$, branched-chain $\alpha$-keto acid dehydrogenase; KIC, $\alpha$-ketoisocaproate; KMV, $\alpha$-keto- $\beta$-methylvalerate; KIV, $\alpha$-ketoisovalerate; IV-CoA, isovaleryl-CoA; MB-CoA, $\alpha$ methylbutyryl-CoA; IB-CoA, isobutyrylCoA. 


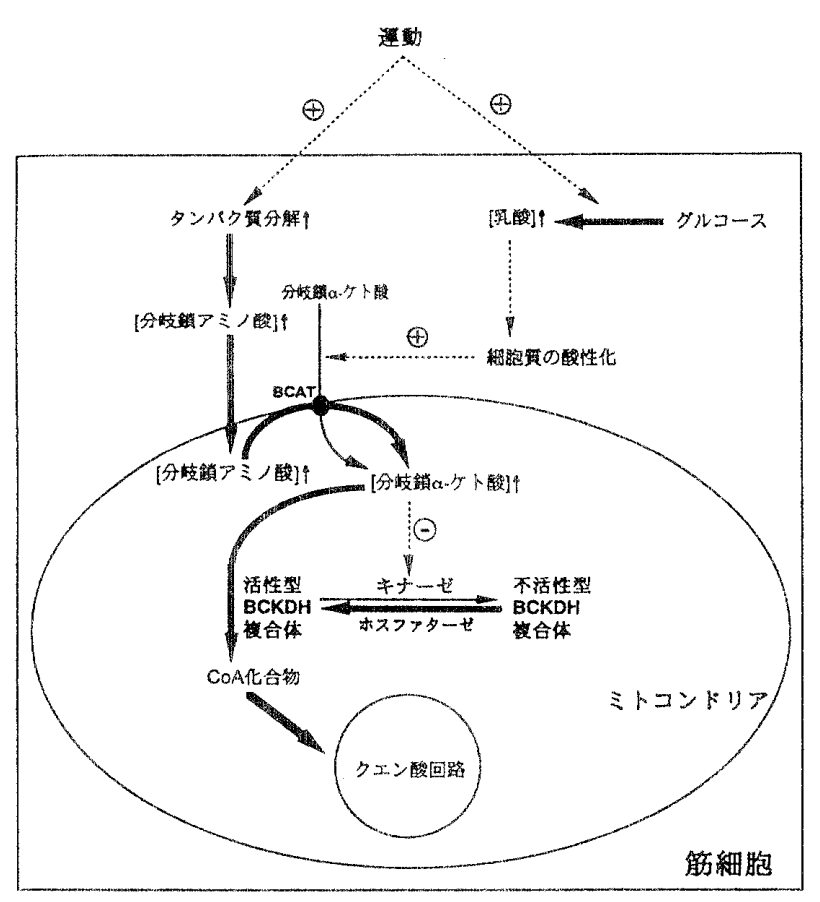

図 8 運動に上る分吱鎖ア三ノ酸分解の促進 (Shimomura,1996より引用)

$\mathrm{BCKDH}$ : 分岐鎖 $\mathrm{BCAT}$ : 分岐鎖アミノ酸アミノ基転移醉素。 運動によるタンパク質分解の促進により， 筋肉中の分佊鎖アミ/酸㴗度が上界する。 筋肉で惊，BCATの活性が高いため，分蚑

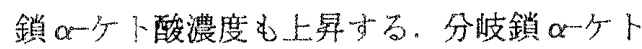
酸の中でロイシンから生成される๙ケトイ ソ力プロン酸は，BCKDHキナーぜの強力 な阻害剤でるらで，キナ一ゼが阻畫され て活性型の醭素が增加し，蓄嫧した分椟鎖 œーケト酸の分解を织進する。一方，運動に よるグルコ一ス分解の促進で乳酸が篦䅡す ると，筋紐胞内加酸性化し，てれにより分 忮鎖 $\alpha-b+$ 酸のミトロソドリアからの漏出

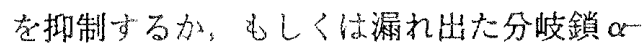
ケト酸のミトコンドリアへの再吸取孛促准 することが明らかにさ机ている。徒って，

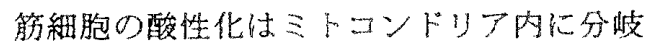

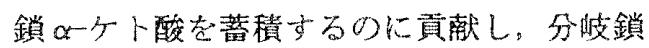
アミノ酸分解を促谁すると考光られる。

らかにされていることは極好わずかであり，今 後多くの研究が必要である. 運動効果の理論的背 景を確拣なものにするためにす，酵素化学や分子 生物学字取り入れた運動生理学の今後の発展が期

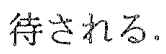

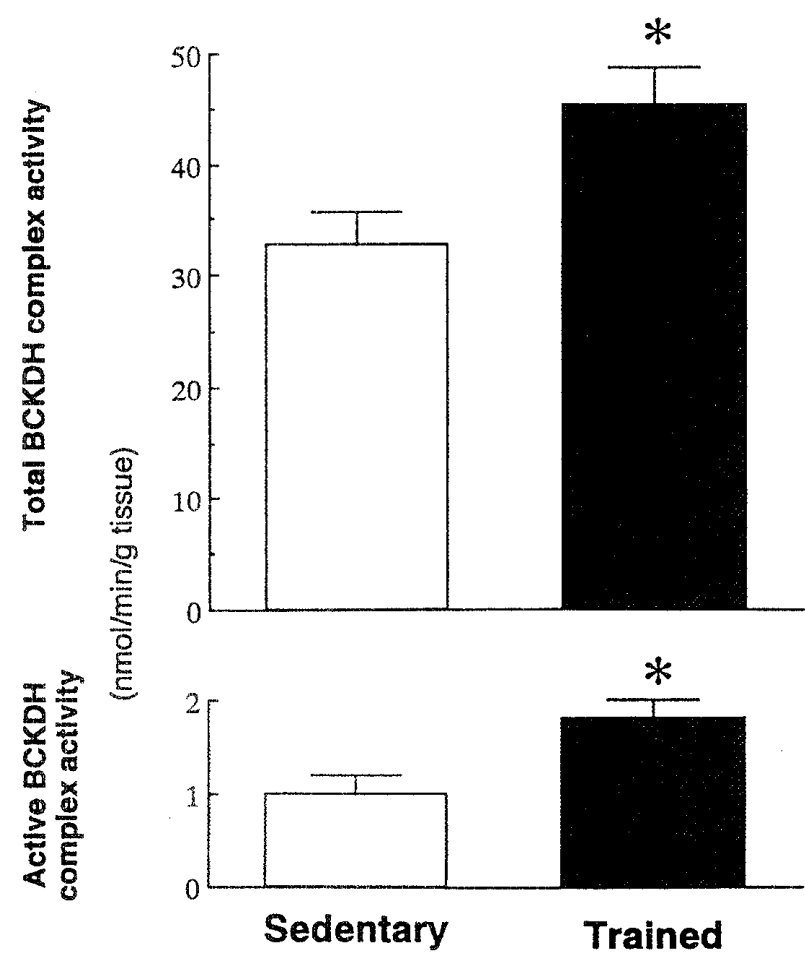

図 9 ラット腓腹筋 BCKDH 複合体の総酵素活性 と活性型酵素活性に対する12週間のトレー ニング効果

各値は平均値と標準誤差で示した（*P< 0.05)。トレーニング群のラットには、トレ ッドミルを用い12週間のトレーニングを負 荷した。トレーニング方法：最終速度 $35 \mathrm{~m} /$ 分，30分/日，5日/週，12週間。(データは Fujii et al., 1995より引用)

女 献

Behal, R. H., Buxton, D. B., Robertson, J. G., and Olson, M. S. (1993) Regulation of the pyruvate dehydrogenase multienzyme complex. Annu. Rev. Nutr. 13: 497-520.

Cano, E. and Mahadevan, L. C. (1995) Parallel signal processing among mammalian MAPKs. Trends Biochem. Sci. 20: 117-122.

Clayton, D. A. (1991) Replication and transcription of vertebrate mitochondrial DNA. Annu. Rev. Cell Biol. $7: 453-478$.

Fujii, H., Shimomura, Y., Tokuyama, K., and Suzuki, M. (1994) Modulation of branched-chain 2-oxo acid dehydrogenase complex activity in rat skeletal muscle by endurance training. Biochim. Biophys. Acta 1.199: 130-136. 
Fujii, H., Tokuyama, K., Suzuki, M., Popov, K. M., Zhao, Y., Harris, R. A., Nakai, N., Murakami, 'T., and Shimomura, Y. (1995) Regulation of physical training of enzyme activity and gene expression of branched-chain 2-oxo acid dehydrogenase complex in rat skeletal muscle. Biochim Biophys. Acta 1243: 277281.

Harper, A. E., Miller, R. H., and Block, K. P. (1984) Branched-chain amino acid metabolism. Annu. Rev. Nutr. 4: 409-454.

Murakami, T., Shimomıra, Y., Fujitsuka, N., Nakai, N., Sugiyama, S., Ozawa, T., Sokabe, M., Horai, S., Tokuyama, K., and Suzuki, M. (1994) Enzymatic and genetic adaptation of soleus muscle mitochondria to physical training in rats. Am. J. Physiol. 267: E388-E395.

Murakami, T., Shimomura, Y., Yoshimura, A., Sokabe, M., and Fujitsuka, N. (1998) Induction of nuclear respiratory factor-1 expression by an acute bout of exercise in rat muscle. Biochim. Biophys. Acta 1381: $113-122$.

Narasimhan, N. and Attardi, G. (1987) Specific requirement for ATP at an early step of in vitro transcription of human mitochondrial DNA. Proc. Nat1. Acad. Sci. USA 84: 4078-4082.

Rabinowwitz, M. and Zak, R. (1975) Mitochondria and cardiac hypertrophy. Circ. Res. 36: 367-376.

Shimomura, Y. (1996) Regulation of branched-chain $\alpha$ keto acid dehydrogenase complex in rat liver and skeletal muscle by exercise and nutrition. In AlphaKeto Acid Dehydrogenase Complexs (Patel, M. S., Roche, T. E. and Harris, R. A., eds.), pp. 177-186, Birkhäuser Verlag, Basel (Switzerland).

Shimomura, Y., Fujii, H., Suzuki, M., Fujitsuka, N., Naoi, M., Sugiyama, S., and Harris, R. A. (1993) Branched-chain 2-oxo acid dehydrogenase complex activation by tetanic contractions in rat skeletal muscle. Biochim. Biophys. Acta 1157: 290-296.

Williams, R. S., Garcia-Moll, M., Mellor, J., Salmons, S., and Harlan, W. (1987) Adaptation of skeletal muscle to increased contractile activity. J. Biol. Chem. 262: 2764-2767.

Williams, R. S., Salmons, S., Newsholme, E. A., Kaufman, R. E., and Mellor, J. (1986) Regulation of nuclear and mitochondrial gene expression by contractile activity. J. Biol. Chem. 261: 376-380. 